\title{
History of education in Switzerland: Historic development and current challenges
}

\author{
La historia de la educación en Suiza: \\ Desarrollo histórico y desafíos actuales
}

\section{L'Histoire de l'éducation en Suisse : Développement historique et défis actuels}

\author{
Michèle Hofmann \\ University of Applied Sciences and Arts Northwestern Switzerland
}

\begin{abstract}
As in other countries, history of education in Switzerland is faced with a number of challenges (for example, job cuts, and questioning of the discipline's role and function). This paper argues that the discipline's current situation can only be adequately understood in light of its eventful history. Therefore, first, the paper deals with the historic development of the history of education in Switzerland. Particular focus is placed on the establishment of the history of education as a part of pedagogy at the institutions of teacher education during the first half of the 19th century, and the discipline's further development over the course of the late 19th and 20 th century. Second, the consequences for the discipline's present and future that arise from its specific, historically evolved situation are discussed.
\end{abstract}

Key words: history of education, disciplinary history, teacher education, Switzerland.

RESUMEN

Como en otros países, la historia de la educación en Suiza se enfrenta con una cantidad considerable de desafíos (por ejemplo: los recortes, el cuestionamiento del rol de la disciplina y la función que posee). Este artículo demuestra que la situación actual de la disciplina solo puede ser entendida adecuadamente a la luz de su historia llena de incidentes. Por lo tanto, en un primer paso el artículo aborda la cuestión del desarrollo histórico de la historia de la educación en Suiza. Se pone particular atención en la fundación de la historia de la educación como parte del campo de la pedagogía en las instituciones de formación de maestros durante la primera parte del siglo XIX y el posterior desarrollo de la disciplina durante el periodo de finales del 
siglo XIX y el siglo XX. En un segundo paso, el artículo trata las consecuencias para el presente y el futuro de la disciplina que resultan de su situación específica y evolución histórica.

Descriptores: historia de la educación, disciplina de la historia, formación de maestros, Suiza.

\title{
RÉSUMÉ
}

Comme dans d'autres pays, l'histoire de l'éducation en Suisse fait face à un nombre de défis (e. g. pertes d'emplois, questionnement du rôle et de la fonction de la discipline). Cet article soutient que la situation actuelle de la discipline ne peut être comprise adéquatement qu’à la lumière de son histoire mouvementée. Dans un premier temps, l'article traite donc du développement historique de l'histoire de l'éducation en Suisse. Je mise en particulier sur l'instauration de l'histoire de l'éducation, comme partie prenante de la pédagogie aux institutions de formation des enseignants durant la première partie du 19e siècle, et sur le développement ultérieur de la discipline au cours de la fin du 19e et du 20e siècle. En un deuxième temps, cet article examine les conséquences pour le présent et l'avenir de la discipline qui surgissent de sa situation spécifique historiquement évoluée.

Mots clés: histoire de l'éducation; histoire disciplinaire;formation des enseignants; la Suisse.

\begin{abstract}
A S IN OTHER COUNTRIES, HISTORY OF EDUCATION IN SWITZERLAND is currently faced with a number of challenges. These include job cuts at universities, the establishment of a 'new' field of activity in teacher education, and the related questioning of the role and function of the discipline (particularly concerning its self-conception, methodology, boundaries, and affiliations). As many other young researchers in the history of education, I am also affected by these recent events. After majoring in history and acquiring a $\mathrm{PhD}$ in history of education, I now work at a teachers college. Therefore, this paper also represents an attempt to understand the discipline I am working in and reflect upon my own professional situation. The state of the history of education today is influenced both by external factors (educational policy, economy) and factors within the sciences (for example, increased focus on quantitative methods, and research funding). However, attempting to explain the present situation through these factors alone falls short of the mark. The main argument I wish to address here is that the current situation of the discipline of history of education can only be adequately understood by taking account of its eventful history. Hence, I will discuss the current challenges that the history of education and its representatives are facing in the light of the discipline's historical development.

Consequently, this paper first focuses on the discipline's historic development. During the process of the establishment of the history of education as a discipline in Switzerland during the 19th and 20th century, the following factors had a particularly strong and lasting impact: the discipline's close link to teacher education and educational practice, its relationship to other academic disciplines (pedagogy, philosophy, and history), and the institutional framework it was embedded in. Secondly, this paper illustrates to what extent these factors are important for understanding the current situation of the history of education. Currently, the discipline is strongly influenced and challenged by the concept of institutional and disciplinary unity of what is called "educational science" and by a revival of its close link to teacher
\end{abstract}


education.

But first, some preliminary contextual details about Switzerland and its education system: Switzerland was and still is a small country. At the beginning of the 19th century, it had a population of 1.6 million, a century later 3.3 million, and today it has 8 million inhabitants (Bundesamt für Statistik, 2014; Head-König, 2002, pp. 365-370). In 1848, the 25 confederate cantons formed a federal state. The new federal constitution guaranteed the continued existence of the Swiss cantons as partially sovereign states. From this point onward, the federal government and the constituent states shared the governmental responsibilities in dualistic interaction. The federal government's powers were very limited and the majority of administrative tasks, including the responsibility for the education system, remained with the cantons (Im Hof, 2001, p. 116, 119). Hence, in the 19th century, the school systems developed at the cantonal level. The cantonal education systems were and still are generally perceived to be very diverse - in fact, since the 19th century, commentators have focused on the differences and idiosyncrasies rather than on what the cantonal school systems in Switzerland have in common. One example amongst many is an article that was published in the Swiss Teachers' Journal in 1864. The article complains about the difficulties that arose when children changed schools from one canton to another (Wellauer, 1864, p. 69). These difficulties were caused by the mandatory school age, the teaching materials, and styles of lettering, all of which differed from canton to canton. Over time, the strong emphasis on the differences between the cantonal school systems led to the familiar reference to Switzerland's "26 school systems" (Brägger, Kramis, \& Teuteberg, 2007, p. 84; Gingins, Labudde, \& Adamina, 2007, p. 230; Stamm et al., 2009, p. 33). This one-sided focus also had an impact on the historiography of education: in contrast to other countries, ${ }^{2}$ Switzerland lacked a national history of schooling - a fact that is still true today and that is repeatedly brought up as a research desideratum (Brändli, 2011, p. 293; Criblez \& Jenzer, 1995, p. 210; Rhyn, 2001, p. 92).

The strong system of federalism in Switzerland also had an effect on the universities and on teacher education. With the exception of the two federal institutes of technology in Zurich (ETH) and Lausanne (EPFL), the universities in Switzerland lie under cantonal sovereignty and thus have their legal basis in cantonal constitutions and laws. Switzerland's first university was founded in Basel in 1460. The majority of the universities in Switzerland were founded in the 19 th century. ${ }^{3}$ Recently, universities were founded in the Italian-speaking canton of Ticino (1996) and in Lucerne (2000). From the very beginning, teacher education was also organized at the cantonal level. For a long time, the education of primary school teachers did not take place at institutes of higher education but at teacher seminars. As a consequence of the increased demand for teachers resulting from the intensified efforts to educate the people, these institutions were founded in various cantons from the 1830s (Grunder, 2007, pp. 749-751). A clear trend towards transferring the education of primary school teachers to institutions of higher education did not become apparent until the end of the 20th century (Ambühl \& Stadelmann, 2010). This trend reached its provisional conclusion with the founding of teachers colleges after the turn of the 21 st 
century. The training programs for secondary school and high school teachers, which had been developed at the universities since the 19th century, were also integrated into the teachers colleges. Currently, 14 such institutions exist in Switzerland, all of which are run by cantons.

\section{From the "history of pedagogics" to the history of education}

According to the relevant research literature, the establishment of the history of education as a discipline in Switzerland was influenced mainly by teacher education (Gonon, 1999). Here, it became part of pedagogics, which established itself as a discipline at the newly founded teacher seminars. This does not mean to say that the teacher seminars were the birthplace of history of education. Historians and philosophers wrote about concepts or experiences relating to the history of education well before or independent of its establishment in teacher education. In the following, however, I will focus on the development of the discipline in the context of teacher education.

Pedagogics at the seminars dealt primarily with the "history of pedagogy," which was the term for history of education at the time. In the second half of the 19th century, pedagogy was also integrated at the universities and here, too, the "history of pedagogy" played an important role. Thus, the history of education was integrated into a dual institutional framework. This circumstance would prove to shape the discipline and will hence be taken into account in the following discussion. The establishment of the science of education at the universities took place in connection with the creation of training programs for teachers. Following the initial high school teacher training courses, secondary school teacher training programs were introduced (Späni, 2002, pp. 90-92). The institutionalization of educational science in the form of professorships started several decades later during the last third of the 19th century. At the University of Berne, a professor extraordinarius for pedagogics was instated in 1870. It was no coincidence that the position was assigned to the director of the teacher seminar in Berne: Hans Rudolf Rüegg (1824-1893) (Rhyn, 2001, p. 201). Several other professorships followed at other Swiss universities in the late 19th and early 20th century (Hofstetter \& Schneuwly, 2011). Here, too, the professors were selected from the circle of lecturers at the teacher seminars. In the late 19th century, pedagogics were expected not only to represent theory, but also educational practice (Herzog, 2002, pp. 271-272).

A number of pedagogics lecturers were renowned school historians (Criblez \& Jenzer, 1995, pp. 213-214). They published textbooks that formed the basis for the teacher-training students' studies. One example is the Geschichte der Erziehung in ibren Grundzügen mit besonderer Berücksichtigung der Volksschule (1901) [An Outline of the History of Education with Special Consideration of the Primary School System] by Emanuel Martig (1839-1906). The cover page of the textbook recommends it as "a publication by an expert in pedagogics who has acquired a far-reaching reputation thanks to his numerous textbooks and workbooks, which have in part already been published in several editions. The success of Martig's books is due to the fact that each and every one is based on his educational experience, albeit being scientifically substantiated" 
(Martig, 1901). Their common orientation towards educational practice led to the textbooks on the history of schooling forming a specific canon that shaped the discipline: the so-called pedagogic "classics." Didactically, these "classics" illustrated the "history of pedagogy" by examining the life and works of the "great" pedagogues, such as Jean-Jacques Rousseau (1712-1778), Johann Heinrich Pestalozzi (17461827), or Philipp Emanuel von Fellenberg (1771-1844) (Criblez, 2002, p. 428; Criblez \& Jenzer, 1995, p. 214; Herzog, 2002, p. 268; Späni, 2002, pp. 84-86). The well-known handbook, Geschichte der Schweizerischen Volksschule [History of Primary Schools in Switzerland], which was published in three volumes in 1881 and 1882, and which is still frequently cited today, is an example of this type of textbook. The handbook was edited by Otto Hunziker (1841-1909), a lecturer at the teacher seminar in Küsnacht near Zurich and a professor of pedagogics and Swiss history of schooling at the University of Zurich. The History of Primary Schools in Switzerland presents a line-up of biographies of eminent educators. This type of history of schooling was intended to provide the teachers in training with important ideological points of reference for their professional conduct (Criblez, 2002, pp. 425-453; Criblez \& Jenzer, 1995, pp. 210-238; Fend, 2004, pp. 110-111; Herzog, 2002, pp. 267-281; Rhyn, 2001, pp. 192-211; Späni, 2002, pp. 77-99). They were to learn the standards for their conduct from the "great" historic role models, and to achieve an assessment of their professional self-conception and their duty as teachers by reading the pedagogic "classics" (Fend, 2004, p. 110). As a result of the popularity of this type of textbook, the discipline as a whole became oriented towards a certain purpose: engraining a professional ethic. History was to serve as a means of creating an ethos and mindset, but not, as the strong orientation of the textbooks towards the "great" pedagogues may suggest, as a pool for possible courses and forms of action. When describing the "great" historic role models, importance was attached not so much to their actual educational activities, but rather to the mental and moral posture that served as the basis for their actions.

When portraying the activities of their "heroes," Hunziker and his co-authors did not intend them to be imitated, but merely for the ethos upon which these (successful and failed) actions were based to be understood and adopted by the next generation of teachers. This intention can be illustrated using Hunziker's article on Johann Heinrich Pestalozzi. Over almost 50 pages, Hunziker (1882) described the life of Pestalozzi (pp. 73-121). His description did not omit the difficulties associated with the founding of Pestalozzi's institutions, particularly disputes and financial problems. He also described the "misfortunes in Pestalozzi's family"; by this, he meant the ill health of Pestalozzi's wife, but also the "concerns about his only son." On the fate of Pestalozzi's son, Hans-Jakob, we learn that "after all kinds of mutually contradicting educational experiments - already at the age of three, Pestalozzi tried to teach him letters and Latin, only to subsequently adhere to Rousseau's principles with such conviction that at the age of twelve, Hans-Jakob was still not able to read or write [he was] sent away from home at an early age, first to the Pfeffelsche Institut, then to a merchant's house in Basel” (Hunziker, 1882, p. 95).

In honor of Jean-Jacques Rousseau, Pestalozzi had named his son Hans-Jakob 
(the German equivalent of Jean-Jacques) and intended to educate him according to the principles that Rousseau formulated in his educational novel Emile in 1762. Pestalozzi recorded his attempt at upbringing in his diary, of which only fragments have survived (Tröhler, 2006b, pp. 223-224). These fragments reveal that at the age of only three and a half, Hans-Jakob suddenly developed an aversion, which was directed particularly against spelling, orthography, and learning Latin. Shortly afterwards, after Pestalozzi had locked him in a cold room, the boy took ill (Tröhler, 2006b, pp. 225-226). As can be gathered from the quotation from Hunziker's article, the result of the experiments was that Pestalozzi's unyielding adherence to Rousseau's principles led to his twelve-year old son's illiteracy. It is noteworthy that all the described difficulties - disputes, financial problems, and the failed educational experiments on his son - do not in any way damage the portrait that Hunziker painted of Pestalozzi in his article. In order to describe Pestalozzi's personality in a "vivid" manner, he quoted Johannes Niederer (1779-1843), Pestalozzi's co-worker of many years (Hunziker, 1882, p. 110). Niederer described Pestalozzi as someone "in whom all the strings of human nature sound or have once sounded. As harmless and indulging as a child; as mild and pleasant, as sensitive in feeling and as sentimental as a woman; as firm and determined in his intents, as daring and assertive as a man; as persistent, self-sacrificing, and willing to overcome obstacles as a hero, and all this from the gentlest emotions and stirrings, during the most diverse situations of life, through all stages, through to sublime enthusiasm and the blissfulness of rapture; [...] that was how Pestalozzi was in person" (Hunziker, 1882, p. 110). And this - Pestalozzi's personality - was precisely what the trainee teachers were to orient themselves by, and not by his actions. The trainee teachers were to learn to think and feel like Pestalozzi, if not necessarily to act as he did.

Hunziker's monumental publication on the history of schooling represents an expression of a golden age of the history of schooling in Switzerland, which started in the 1870s (Criblez \& Jenzer, 1995, pp. 210, 217-219). Institutionally, this golden age was also reflected by permanent exhibitions and museums. Hunziker was not only the first professor extraordinarius for the history of pedagogy and Swiss history of schooling, but also the director of the first permanent school exhibition in Switzerland. The exhibition was founded in Zurich in 1875. In the following years, school museums and exhibitions were founded in numerous other cities in Switzerland. Furthermore, in 1885, the "association for studies in history of schooling in Switzerland" was founded. In many cantons, large-scale studies on school history were carried out (Fluri, 1906; Mösch, 1910-1918). As mentioned in the introduction, these and later studies did not use the nation as a point of reference, but rather the cantons or regions.

The high value placed on the historic approach in pedagogics was owed not least to its close link to teacher education and educational practice (Tröhler, 2006a, pp. 550-554). As explained above, this link not only influenced the appointment of professorships, but also led to the development of specific textbooks and brought about a specific manifestation of the genre. As shown, this genre consisted of the exploration of the "history of pedagogy" on the basis of the examples set by the "great" educators. This "hagiography" was by no means limited to the 19th century. On the contrary, it 
has remained to this day a defining factor for this discipline (Gonon, 1999, p. 529). To name just one example: Albert Reble's Geschichte der Pädagogik [History of Pedagogy] has been published in 22 editions since 1951 - most recently in 2009. In this book, Reble describes eight periods of pedagogic thinking, mainly with reference to their most eminent pedagogues, philosophers and writers such as Rousseau, Humboldt, Goethe, Kant, Pestalozzi, Fröbel, or Herbart.

Within general history, "hagiographies" came under criticism some time ago. The "great" men came under pressure from feminist historiography, became beleaguered by "the common man" (that is, history of everyday life, history "from below") and disempowered by structural history. Within the history of education, it was not until the late 20th century that this type of historiography started to be called into question. This led to an eager rereading of the "classics," a process that was regarded by its followers as criticism of pedagogic dogmas and myths (Schmid, 2004, p. 108). Although this critical rereading turned the hagiography into an "anti-hagiography," the focus remained on the pedagogic "classics." "This development resulted, on one hand, in a limited range of topics, which has only recently been expanded, and on the other hand, it was one of the causes for the discipline's limited ties to historical science.

Until the middle of the 20th century, the history of education formed an important part of pedagogy at the universities in the German-speaking part of Switzerland, even though on the whole, the importance of research into the history of schooling had been decreasing since the 1920s (Criblez \& Jenzer, 1995, p. 219; Späni, 2011, p. 388, 400). In the 1960s and 70s, "a phase of more rapid decline" of the history of schooling began (Criblez \& Jenzer, 1995, p. 219). This development was triggered mainly by the "realistic turn." Called for by Heinrich Roth (1906-1983), this "turn" - "which one can perhaps better describe as an empirical turn or the orientation of pedagogy towards the social sciences" - resulted in the departure from the prevailing philosophical and historical orientation of education as an academic discipline (which had already taken place in the French-speaking part of Switzerland at the beginning of the 20th century) ${ }^{5}$ (Criblez $\&$ Jenzer, 1995, p. 222). In the course of this development, a specialization and differentiation of what was now called "educational science" took place; various sub-disciplines were formed, which were also referred to as "hyphen-pedagogies" (Criblez, 2002, p. 310). In the 1960s and 1970s, one of the sub-disciplines to emerge was the history of education (Fuchs, 2008; Herzog, 2002). The corresponding professorships were integrated into the educational science institutes at the universities. This institutional embedding of the history of education also took place in conjunction with another sub-discipline of educational science: so-called "general education." Chairs in this joint sub-discipline were typically called "general and historical education." The result of this construction was that only researchers who had achieved a habilitation in educational science were entitled to apply for a professorship; historians, on the other hand, were not eligible because they were not qualified for "general education." Thus, the establishment of the history of education as a part of historical science was greatly impaired. Contact to history was further impaired by the fact that educational science had different reference disciplines. For 
a long time, pedagogy at the universities was strongly oriented towards philosophy. For the "history of pedagogy" this had meant that - embedded within the broader context of education as an academic discipline - it had also been strongly influenced by philosophy. Nevertheless, within the new framework, increased efforts were put into "establishing the history of education as a part of general historiography and thus into distancing the discipline from the special status that was associated with its close link to teacher training” (Horlacher, 2009, p. 419).

Based on the thesis of this paper, the following section will demonstrate that the factors that shaped the development of history of education in the 19th and 20th century (close link to teacher education and educational practice, relationship to other disciplines, and institutional framework) are of great importance when attempting to understand the challenges that the history of education faces today.

\section{Current challenges for the history of education}

As mentioned above, the history of education today is embedded within educational science. Notwithstanding the diversity of the discipline, reference continues to be made to the necessity of maintaining the unity of educational science. ${ }^{6}$ This unity is advocated with regard to research topics, research questions, and not least to methodology. However, in everyday academic life, links in research and teaching between the sub-disciplines of educational science are scarce. Contact is confined to the common institutional framework; mutual understanding is limited. Research is performed within different projects, results are presented at separate conferences and published in separate journals, lectures take place in separate courses. Thus, unity within the discipline exists mainly only as a concept. Against this backdrop and considering the claimed intention of historians of education of establishing their discipline as a part of general historiography, the following is interesting to note: in Switzerland - in contrast to other countries ${ }^{7}$ - the association of history of education with the discipline of educational science and its institutes has yet to be called into question. The history of education continues to be understood and advocated as a part of educational science. ${ }^{8}$ It appears that in Switzerland, the concept of unity with regard to the institutions and the discipline of educational science as an academic discipline that combines a variety of paradigms is very pervasive. ${ }^{9}$ In this respect, the historic roots appear to have a strong and lasting impact.

The argument regarding the necessity of disciplinary unity also asserts the claim that the various sub-disciplines of educational science (including the history of education) can only be practiced adequately by researchers who consider themselves educational scientists and who have undergone the appropriate education. ${ }^{10}$ The reality, however, is different. The recent expansion of the traditional spectrum of subjects and the widening of the range of permissible types of sources means that, particularly in Switzerland, not only educational scientists are active as researchers in the history of education, but also increasingly historians, sociologists, psychologists, or philosophers (Horlacher, 2009, p. 419). This constellation offers an exciting environment, the potential of which, however, should be put to better use - for example, in the form of a historico-cultural approach to the history of education and schooling. ${ }^{11}$ If 
historical research is understood in this way, it focuses, for example, on schools as institutions of knowledge transfer. On one hand, schools are places where knowledge transfer takes place across generations. On the other, there is a transfer of knowledge between schools and other social spheres (for example, the healthcare system, the military, or scientific disciplines) - a process that takes place in both directions. However, knowledge is not only transferred but also transformed (Fontaine, 2013). In this context, questions such as the following arise. What knowledge found its way into the schools (and why)? How was this knowledge adapted and modified for the schools and by the schools? To what extent was this knowledge disseminated by the schools? Who was involved in the processes of transfer and transformation, and in which form? By seeking answers to these and other questions, the history of education can contribute towards cultural history in general and in particular towards the "history of knowledge" (Sarasin, 2011). In this process, the exchange between researchers from educational science, sociology, psychology, philosophy, philology, or history can be very stimulating and assist in shaking off perceived narrow disciplinary boundaries. However, this development, which in principle is to be welcomed, also encompasses problems. The difficulties lie in achieving a consensus about methodical and other scientific standards. If one cannot orient oneself by means of established common disciplinary standards, one runs the risk of arbitrariness. ${ }^{12}$ In addition, the history of education also faces the challenge that, nowadays, educational science is influenced by theories and particularly methods from the social sciences. If the history of education wishes to cope with this development in the future, it must either increase its efforts to integrate such theories and methods, or widen the awareness for its genuinely endemic theories and methods.

The question regarding the future of the discipline also relates to its institutional framework. The assessment of the German historian of education Eckhardt Fuchs regarding the state of the history of education in Europe and in the English-speaking countries also holds true for Switzerland: a process of deinstitutionalization at the universities coincides with a period of active scientific productivity (publications, research projects) (Fuchs, 2008, pp. 269, 291-292; Fuchs, 2010, pp. 712-719). Depending on one's area of focus, the state of the academic discipline can thus be assessed either as precarious or successful. ${ }^{13}$ In recent years, the retirement of recognized historians of education and the appointment of professors who have different research profiles has led to the history of education losing prominence at Swiss universities. ${ }^{14}$ With regard to the job situation for historians of education, the teachers colleges, which were founded after the turn of the 20th century, created new opportunities. Over the last ten years, positions for historians of education in research and teaching have been created at these institutions. (However, the number of jobs created is limited and many of the positions are based on fixed-term contracts. $)^{15}$ The teachers colleges do not offer their own degree programs in educational science and, on the whole, educating the students in matters of scientific methodology does not play a significant role. Historical methods and theories are scarcely included in the curricula. Moreover, the teachers colleges do not have the right to award doctorates. In consequence, they are dependent on the universities when it comes to introducing 
young researchers to careers in the history of education. In view of the discipline's loss of importance at the universities, the question arises as to where young researchers are to come from in the future.

In the light of this rather grim outlook, a line is now to be drawn to a topic that was dealt with in detail at the beginning of this paper: the close relationship between the history of education and teacher education. Analogous to the situation at the universities, the teachers colleges set up the history of education as a part of educational science. ${ }^{16}$ In view of the discipline's historic development, this is hardly surprising. Reference to the discipline's historically determined importance appears to remain a valid argument in favor of this constellation. However, with recourse to its content, it is not easy to justify why the history of education should remain a part of teacher education, since, as explained above, it is no longer possible to tie it in with the tradition of the 19th and 20th century. ${ }^{17}$ With regard to the situation in France, Pierre Caspard and Rebecca Rogers (2012) formulated this difficulty as follows: "contemporary schools are confronted by a series of problems that the history of education is ill equipped to illuminate" (p. 79). This assessment also applies to Switzerland. How, then, can the history of education find its place at the teachers colleges?

In contrast to the universities, the Swiss teachers colleges today have the mission and the claim of conducting research that is oriented towards the teaching profession (Schweizerische Konferenz, 1993, p. 9). In this context, we speak of "utility-oriented basic research." On one hand, this orientation introduces a clearly defined circle of addressees: the teachers in training. On the other, it is associated with the concept that this form of (educational) research must produce a benefit for educational practice (Reinders, Gräsel, \& Ditton, 2011). However, complaints continue to be aired that this has not been adequately achieved (Fischer, Waibel, \& Wecker, 2005). Against this backdrop, the following issues are discussed within the discipline. Should the history of education provide teachers in training with reflexive knowledge - in other words, knowledge that enables them to achieve a better understanding of the current school system based on its history? Or should history of education (also) be a source of practical and governing knowledge - that is, provide historical knowledge on the basis of which teachers can contribute towards shaping current and future school reforms? Either way, the question also arises as to whether the exclusive orientation towards teachers in training requires a specific genre of the history of education, as has been the case in the past. In other words, should the history of education at the teachers colleges differ from the history of education at the universities? In my opinion, the answer to this last question should be a negative. In the light of the process of deinstitutionalization at the universities and the methodological challenges that the history of education faces, it is highly doubtful that such a fragmentation would be beneficial - on the contrary, it would constitute an additional weakening of the discipline. As a first priority, historians of education - regardless of whether they work at universities or teachers colleges - should endeavor to conduct high-quality research in order to assert themselves within this tough environment. Furthermore, it would be desirable to establish a close collaboration between the various groups of researchers that are active in the history of education - across institutional, regional, 
and also national boundaries.

The main argument this paper wished to address is that the current situation of the history of education can only be adequately understood by taking account of its eventful history. Nevertheless, no matter how important it is to know the discipline's history in order to understand the struggles it faces in academic research and in teacher training today, history does not provide us with answers to the question concerning the actual relevance of this academic discipline. Every age is next to God, the German historian Leopold von Ranke (1795-1886) argued (Ranke, 1971, p. 60), which in the case discussed in this paper also means that every generation of historians of education must find their own solutions to the challenges they face.

\section{Notes}

1. Since 1979, Switzerland consists of 26 cantons and half-cantons. The youngest constituent state, the canton of Jura, was approved in a nationwide referendum in September 1978.

2. For Germany, a six-volume Handbuch der deutschen Bildungsgeschichte (19872005) [Manual of German History of Education] was published. Similarly extensive publications are available for France, Austria, and Spain. National monographs on research into the history of schooling can also be found, for example, for Italy and Ire-land.

3. Zurich (1833), Berne (1834), Neuchâtel (1838), Geneva (1873), Fribourg (1889), Lausanne (1890), St. Gallen (1898).

4. Examples include the habilitation theses of Fritz Osterwalder (1996) and Daniel Tröhler (2006b). The former deals with the impact and reception of Pestalozzi with regard to the emergence of modern educational science. The latter is an impressive study on republicanism in Switzerland - here too, the focus is on Pestalozzi.

5. After 1900, an "experimental" reorientation of pedagogy took place in the French-speaking part of Switzerland. Such attempts remained unsuccessful in the German-speaking part of Switzerland (Criblez, 2010; Hofstetter, 2011).

6. In this context, some researchers talk about the dignity of the discipline.

7. At the beginning of the 21 st century, for example, an intensive debate took place in the US during which the disciplinary association of the history of education was discussed. Its position between the traditional historic disciplines and departments on one hand, and the educational science environment and teacher education on the other, was determined to be a problem (Schuch, Tenorth, \& Welter, 2010, p. 645).

8. However, there are currently certainly isolated links to historical science, such as the active collaboration of educational historians in the Swiss society for research into the 18th century or the Zurich history of education workshop, where doctoral students of educational and historical science present their studies on subjects relating to the history of education. In 2015, the workshop will take place for the fourth 
time.

9. Naturally, one can raise the question as to the state of this unity during the 19th century. However, the question whether this past unity was real or simply advocated is irrelevant for the current situation.

10. This reasoning may well be attributed not least to the defense of the educational science (particularly of the professorships) against academics from other disciplines. Moreover, this reasoning counteracts the question concerning the very need for educational science, or whether the various "hyphen-pedagogies" would not be better off if integrated into psychology, history, sociology, and so on.

11. The term "culture" is used in an attempt to "capture preferably all aspects of physical, social and mental life" (Horlacher, 2009, p. 418).

12. This point was also referred to by the German historian of education Edith Glaser during a debate on the situation and the future of the history of education at the DGfE Congress 2014 in Berlin. She raised the question of whether the history of education requires authoritative scientific standards.

13. This was also made clear during a discussion regarding the situation and future of the history of education (in Switzerland), which was held at the DGfE Congress 2014 in Berlin.

14. Currently, within a university environment, research in the history of education is practiced by researchers at institutes of education at the universities of Zurich and Geneva, and by historians at history departments at the universities of Bern and Lausanne.

15. To a certain extent, the institutionalization of the discipline also resulted in setbacks. Between 2002 and 2008, an institute for history of education existed at the Zurich University of Teacher Education. It was the successor institute of the Pestalozzianum (Institute for the advancement of the school and educational sector and for Pesta-lozzi research in Zurich), formerly the permanent school exhibition. Now, this teachers college has a center for the history of schooling.

16. This is probably most visible at the School for Teacher Education at the University of Applied Sciences and Arts Northwestern Switzerland. Here, the various departments are divided into professorships. The professorship for general and historical education is assigned to the educational science department.

17. As is demonstrated by the international debates on this subject, it is no longer possible to give simple answers to the question regarding the benefit of the history of education for teacher education (Depaepe, 2001; Depaepe, 2010, pp. 34-49; Kliebard, 2004, pp. 96-111; the discussion about the question 'Aus der (Bildungs-) Geschichte lernen?' [Learning from history (of education)?], which Thomas Koinzer and Rüdiger Loeffelmeier raised in the journal Zeitschrift fürpädagogische Historiographie; Tröhler, 2011, pp. 9-22). 


\section{References}

Ambühl, H., \& Stadelmann, W. (Eds.). (2010). Tertiarisierung der Lebrerinnen- und Lehrerbildung: Bilanztagung I. Bern, Switzerland: EDK.

Brägger, G., Kramis, J., \& Teuteberg, H. (2007). Reform der Schulaufsicht und Aufbau der Externen Schulevaluation in der Schweiz am Beispiel der Kantone Luzern und Thurgau. In H.-G. Kotthoff (Ed.), Schulinspektion: Evaluation, Rechenschaftslegung und Qualitätsentwicklung (pp. 65-91). Münster, Germany: Waxmann.

Brändli, S. (2011). Skylla und Charybdis in der Bildungsgeschichte: Methodische und perspektivische Bemerkungen zur disziplinären Entwicklung in der Schweiz. Schweizerische Zeitschrift für Geschicbte, 61, 290-314.

Bundesamt für Statistik. (2014). Bevölkerungsstand und Bevölkerungswachstum. http:// www.bfs.admin.ch/bfs/portal/de/index/themen/01/02/blank/key/bevoelkerungsstand. html

Caspard, P., \& Rogers, R. (2012). The history of education in France: A laboriously useless science? In J. E. Larsen (Ed.), Knowledge, politics and the history of education (pp. 73-85). Berlin, Germany: Lit.

Criblez, L., \& Jenzer, C. (1995). Zur Situation und Entwicklung der Schulgeschichte in der Schweiz: 'Aber warum sprechen wir von der Vergangenheit und der Gegenwart? Die Realität ist ein unteilbares Ganzes.' Bildungsforschung und Bildungspraxis, 17, 210-238.

Criblez, L. (2002). Fragil und unstet: Zur Entwicklung der Erziehungswissenschaften an den Universitäten der deutschsprachigen Schweiz. In R. Hofstetter and B. Schneuwly (Eds.), Erziehungswissenschaft(en) 19.-20. Jahrbundert: Zwischen Profession und Disziplin (pp. 425-453). Bern, Switzerland: Lang.

Criblez, L. (2002). Wozu Pädagogik? Zum Funktionswandel der Pädagogik in der Lehrerbildung. Beiträge zur Lehrerbildung, 20, 300-318.

Criblez, L. (2010). Experimentelle Didaktik: Aspiration und 'Scheitern' eines wissenschaftlichen Programms anfangs des 20. Jahrhunderts. In P. Bühler, T. Bühler, \& F. Osterwalder (Eds.), Grenzen der Didaktik (pp. 61-78). Bern, Switzerland: Haupt.

Depaepe, M. (2001). A professionally relevant history of education for teachers: Does it exist? Paedagogica Historica, 37, 631-640. http://dx.doi.org/10.1080/0030923010370305

Depaepe, M. (2010). The Ten Commandments of good practices in history of education research. Zeitschrift für pädagogische Historiographie, 16, 31-34.

Fend, H. (2004). Kommentar zu Kliebards 'Wozu Geschichte der Pädagogik?' Zeitschrift für pädagogische Historiographie, 10, 110-111.

Fischer, F., Waibel, M., \& Wecker, C. (2005). Nutzenorientierte Grundlagenforschung im Bildungsbereich. Zeitschrift für Erziebungswissenschaft, 8, 427-442. http://dx.doi. org/10.1007/s11618-005-0149-7

Fluri, A. (1906). Die bernische Schulordnung von 1591 und ibre Erläuterungen und Zusätze bis 1616. Berlin, Germany: Hofmann.

Fontaine, A. (2013). Transferts culturels et déclinaisons de la pédagogie européenne: Le cas franco-romand au travers de l'itinéraire d'Alexandre Daguet (1816-1894) (PhD dissertation). University of Fribourg, Switzerland. http://ethesis.unifr.ch/theses

Fuchs, E. (2008). Die historische Bildungsforschung im Spiegel ihrer Fachzeitschriften: ein 
Überblick. Jahrbuch für historische Bildungsforschung, 14, 269-296.

Fuchs, E. (2010). Historische Bildungsforschung in internationaler Perspektive: Geschichte Stand - Perspektiven. Zeitschrift für Pädagogik, 56, 703-724.

Gingins, F., Labudde, P., \& Adamina, M. (2007). Bildungsstandards Naturwissenschaften in der Schweiz: Work in progress. In D. Höttecke (Ed.), Naturwissenschaftlicher Unterricht im internationalen Vergleich (pp. 230-232). Berlin, Germany: Lit.

Gonon, P. (1999). Historiographie als Erziehung: Zur Konstitution der pädagogischen Geschichtsschreibung im 19. Jahrhundert. Zeitschrift für Pädagogik, 45, 521-530.

Grunder, H.-U. (2007). Lehrerseminar. In Historisches Lexikon der Schweiz (Vol. 7). Basel, Switzerland: Schwabe.

Head-König, A.-L. (2002). Bevölkerung. In Historisches Lexikon der Schweį (Vol. 2). Basel, Switzerland: Schwabe.

Herzog, W. (2002). Die Pädagogik als Wissenschaft und als Profession: Von der Identität zur Partnerschaft. In R. Hofstetter \& B. Schneuwly (Eds.), Erziehungswissenschaft(en) 19.-20. Jabrbundert: Zwischen Profession und Disziplin (pp. 267-281). Bern, Switzerland: Lang.

Hofstetter, R., \& Schneuwly, B. (Eds.). (2011). Zur Geschichte der Erziehungswissenschaften in der Schweiz: Vom Ende des 19. bis zur Mitte des 20. Jahrbunderts. Bern, Switzerland: hep.

Hofstetter, R. (2011). Genf: Von der Pädagogik als Teil der Geisteswissenschaften zu den Erziehungswissenschaften: Entstehung und Entwicklung eines (pluri-)disziplinären Feldes (1890-1950). In R. Hofstetter \& B. Schneuwly (Eds.), Zur Geschichte der Erziehungswissenschaften in der Schweiz: Vom Ende des 19. bis zur Mitte des 20. Jahrbunderts (pp. 113-143). Bern, Switzerland: hep.

Horlacher, R. (2009). Historische Methoden. In S. Andresen, R. Casale, T. Gabriel, R. Horlacher, S. L. Klee, \& J. Oelkers (Eds.), Handwörterbuch Erziehungswissenschaft (pp. 410423). Weinheim, Germany: Beltz.

Hunziker, O. (Ed.). (1881-1882). Geschichte der Schweizerischen Volksschule in gedrängter Darstellung mit Lebensabrissen der bedeutenderen Schulmänner und um das schweizerische Schulwesen besonders verdienter Reformer bis zur Gegenwart (2 vols.). Zürich, Switzerland: Schulthess.

Hunziker, O. (1881). Heinrich Pestalozzi (1746-1827). In O. Hunziker (Ed.), Geschicbte der Schweizerischen Volksschule in gedrängter Darstellung mit Lebensabrissen der bedeutenderen Schulmänner und um das schweizerische Schulwesen besonders verdienter Reformer bis zur Gegenwart (Vol. 2, pp. 73-121). Zürich, Switzerland: Schulthess.

Im Hof, U. (2001). Geschichte der Schweiz. Stuttgart, Germany: Kohlhammer.

Kliebard, H. M. (2004). Wozu Geschichte der Pädagogik? Zeitschrift für pädagogische Historiographie, 10, 90-96.

Martig, E. (1901). Geschichte der Erziehung in ihren Grundzügen mit besonderer Berücksichtigung der Volksschule, nebst einem Anbang über die Entwicklung des Volksschulwesens in der Schweiz für Lehrer- und Lehrerinnen-Seminare, sowie zum Selbstunterricht. Bern, Switzerland: Schmid \& Francke.

Mösch, J. (1910-1918). Die solothurnische Volksschule vor 1830 (4 vols.). Solothurn, Switzerland: Gassmann.

Osterwalder, F. (1996). Pestalozzi - ein pädagogischer Kult: Pestalozzis Wirkungsgeschichte in der Herausbildung der modernen Pädagogik. Weinheim, Germany: Beltz.

Ranke, L. von. (1971). Ueber die Epochen der Neueren Geschicbte: Vorträge dem Könige Maximilian 
II. von Bayern gehalten (T. Schieder \& H. Berding, Eds.). München, Germany: Oldenbourg.

Reble, A. (2009). Geschichte der Pädagogik. Stuttgart, Germany: Klett-Cotta.

Reinders, H., Gräsel, C., \& Ditton, H. (2011). Praxisbezug Empirischer Bildungsforschung.

In H. Reinders, H. Ditton, C. Gräsel, \& B. Gniewosz (Eds.), Empirische Bildungsforschung: Gegenstandsbereiche (pp. 221-233). Wiesbaden, Germany: VS Verlag. http://dx.doi. org/10.1007/978-3-531-93021-3_19

Rhyn, H. (2001). Die Pädagogik in der Schweiz: Eine Skizze. In K.-P. Horn (Ed.), Erziebungswissenschaft in Mitteleuropa: Aufklärerische Traditionen, deutscher Einfuss, nationale Eigenständigkeit (pp. 192-211). Budapest, Hungary: Osiris.

Sarasin, P. (2011). Was ist Wissensgeschichte? Internationales Archiv für Sozialgeschicbte der deutschen Literatur, 36, 159-172.

Schmid, P. (2004). Lob des V-Effekts. Zeitschrift für pädagogische Historiographie, 10, 108-109.

Schuch, J., Tenorth, H.-E., \& Welter, N. (2010). Historische Bildungsforschung Innovation und Selbstreflexion: Einführung in den Thementeil. Zeitschrift für Pädagogik, 56, 643-647.

Schweizerische Konferenz der kantonalen Erziehungsdirektoren (EDK). (1993). Thesen zur Entwicklung Pädagogischer Hochschulen. Bern, Switzerland: Kürzi.

Späni, M. (2002). Zur Disziplingeschichte der Pädagogik in der Schweiz aus der Perspektive der Lehrstuhlentwicklung zwischen 1870 und 1950. In R. Hofstetter \& B. Schneuwly (Eds.), Erziehungswissenschaft(en) 19.-20. Jahrbundert: Zwischen Profession und Dis₹iplin (pp. 77-99). Bern, Switzerland: Lang.

Späni, M. (2011). Sozialisation in die Erziehungswissenschaften: Zwischen disziplinärer und berufsvorbereitender Logik. In R. Hofstetter \& B. Schneuwly (Eds.), Zur Geschichte der Erziehungswissenschaften in der Schweiz: Vom Ende des 19. bis zur Mitte des 20. Jahrbunderts (pp. 377-408). Bern, Switzerland: hep.

Stamm, M., Ruckdäschel, C., Niederhauser, M., \& Templer, F. (2009). Scbulabsentismus: Ein Pbänomen, seine Bedingungen und Folgen. Wiesbaden, Germany: VS Verlag für Sozialwissenschaften.

Tröhler, D. (2006a). Lehrerbildung, Nation und pädagogische Historiographie: Die 'Geschichte der Pädagogik' in Frankreich und Deutschland nach 1871. Zeitschrift für Pädagogik, 52, 540-554.

Tröhler, D. (2006b). Republikanismus und Pädagogik: Pestalozzi im historischen Kontext. Bad Heilbrunn, Germany: Klinkhardt.

Tröhler, D. (2011). Historiographische Herausforderungen der Bildungsgeschichte. Bildungsgeschichte: International Journal for the Historiography of Education, 1, 9-22.

Wellauer, J. K. (1864). Ein Wort über den durch Translokation vieler Familien erfolgenden Schülerwechsel. Schweizerische Lehrerzeitung, 9. 
